\title{
Reworked Carboniferous palynomorphs from the Lower Jurassic of Bornholm and their palaeogeographic significance.
}

\author{
LARS HENRIK NIELSEN AND EVA B. KOPPELHUS
}

\begin{abstract}
Nielsen, L.H. \& Koppelhus, E.B.: Reworked Carboniferous palynomorphs from the Lower Jurassic of Bornholm and their palaeogeographic significance. Bull. geol. Soc. Denmark, vol. 38, pp. 253-266, Copenhagen, February 19th, 1991. https://doi.org/10.37570/bgsd-1990-38-22

Reworked Carboniferous palynomorphs are found in the Lower Jurassic Rønne Formation on Bornholm. Carboniferous sediments are unknown in the Jurassic provenance areas, which were the Fennoscandian Shield and local highs in the Bornholm area. Their presence is thus of importance to interpretations of Carboniferous palaeogeography.

The northern-limit of proven Carboniferous sediments mainly follows the southern margin of the Ringkøbing-Fyn Arkona High. However, structural evidence suggests that this limit is attributed to post-depositional uplift, faulting and erosion. The reworked palynomorphs indicate that Carboniferous sediments were originally deposited north of their present area of distribution. Down-faulting related to Permo-Carboniferous extension led to the preservation of Carboniferous deposits until uplift made the deposits available for erosion during the Late Triassic and Jurassic.
\end{abstract}

Lars Henrik Nielsen and Eva B. Koppelhus, Geological Survey of Denmark, Thoravej 8, DK-2400 Copenhagen NV, June 20th, 1990.

\section{Introduction}

Large numbers of samples for palynological analysis have been collected from outcrops of Lower and Middle Jurassic sediments on Bornholm in order to refine earlier stratigraphic schemes of Gry (1969), Gravesen, Rolle \& Surlyk (1982) and Hoelstad (1985). The samples from the Lower Jurassic contain a fair number of Carboniferous palynomorphs together with a Hettangian to Sinemurian assemblage (Koppelhus 1988). The aim of this paper is to describe the reworked palynomorphs and to discuss their provenance and palaeogeographic implications.

\section{Geological setting}

The island of Bornholm is located within the Fennoscandian Border Zone and constitutes a complex fault block mosaic (fig. 1). The northeastern two thirds of Bornholm consist of Precambrian crystalline basement rocks, whereas an incomplete Palaeozoic and Mesozoic succession is preserved in downfaulted blocks along the western and southwestern coasts (fig. 2). Palaeozoic and Mesozoic tectonic movements and seale- vel fluctuations have resulted in numerous hiatuses (fig. 3), the longest being that encompassing the Upper Silurian to Middle Triassic. Lower Jurassic deposits rest on both lower Palaeozoic and Upper Triassic rocks (Gry 1969).

The structural elements of Bornholm and the surrounding areas have been defined by onshore and offshore mapping (Gry 1969, Gravesen et al. 1982, Vejbæk 1985, Liboriussen, J., Ashton, P. \& Tygesen, T. 1987, Jensen \& Hamann 1989). The Rønne Graben, which is one of the major tectonic elements, straddles the west coast of the island (fig. 2). It is bounded by northeast-southwest trending normal faults which merge to the north and consists of a number of individual fault blocks. To the south the graben continues into the Gryfice Graben of offshore East Germany and Poland. The Rønne Graben was probably initiated in late Carboniferous to early Permian times as a pull apart basin by fault movements in a transtensional dominated dextral wrench system (Vejbæk 1985, Liboriussen et al. 1987). Part of the Mesozoic graben fill is exposed on Bornholm as a result of the Late Cretaceous to early Tertiary Laramide inversion which led to vertical movements of the order of $1 \mathrm{~km}$ for the RønneHasle Fault Block (fig. 2). Contemporaneous 


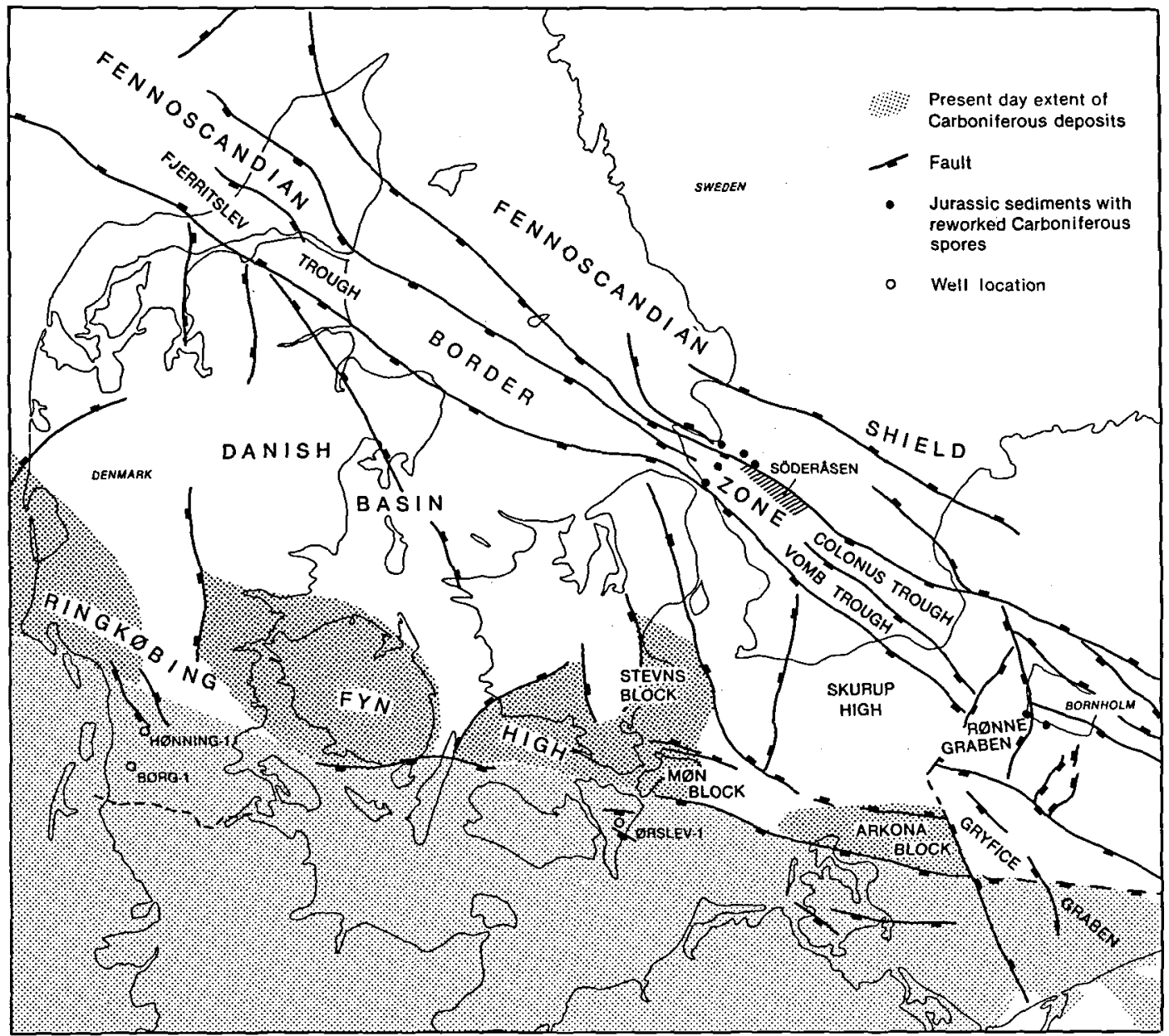

Fig. 1. Tectonic map of the Danish Basin, the Fennoscandian Border Zone and the Danish-Polish Trough.

sediments deposited on the Arnager-Sose Fault Block can be studied in outcrops on the south coast.

\section{Reworked Carboniferous palynomorphs}

\section{Material}

The analysed material was collected from the type sections of the members of the Lower Jurassic Rønne and Hasle Formations, and from the Middle Jurassic Bagå Formation. These exposures comprise only a minor part of the complete succession.

The Munkerup Member, the lowermost part of the Rønne Formation, is exposed in a $2 \mathrm{~m}$. high section of clay from which 3 samples were collected. The overlying Sose Bugt Member of the Rønne Formation (fig. 4) crops out in Sose Bugt where 18 samples were collected. The localities of the two members on the south coast of Bornholm occur within the Arnager-Sose Fault Block (fig. 2). The uppermost Galgeløkke Member of the Rønne Formation is exposed in the Galgeløkke coastal cliff just south of Rønne. 10 samples were collected from here (fig. 4).

Four were also taken from the type locality of the Hasle Formation to the south of the town of Hasle.

The Bagå Formation is well exposed in the clay pit of the Hasle Klinkerfabrik on the west coast of Bornholm from which 17 samples were collected. The last three localities occur within the Rønne-Hasle Fault Block (fig. 2). 


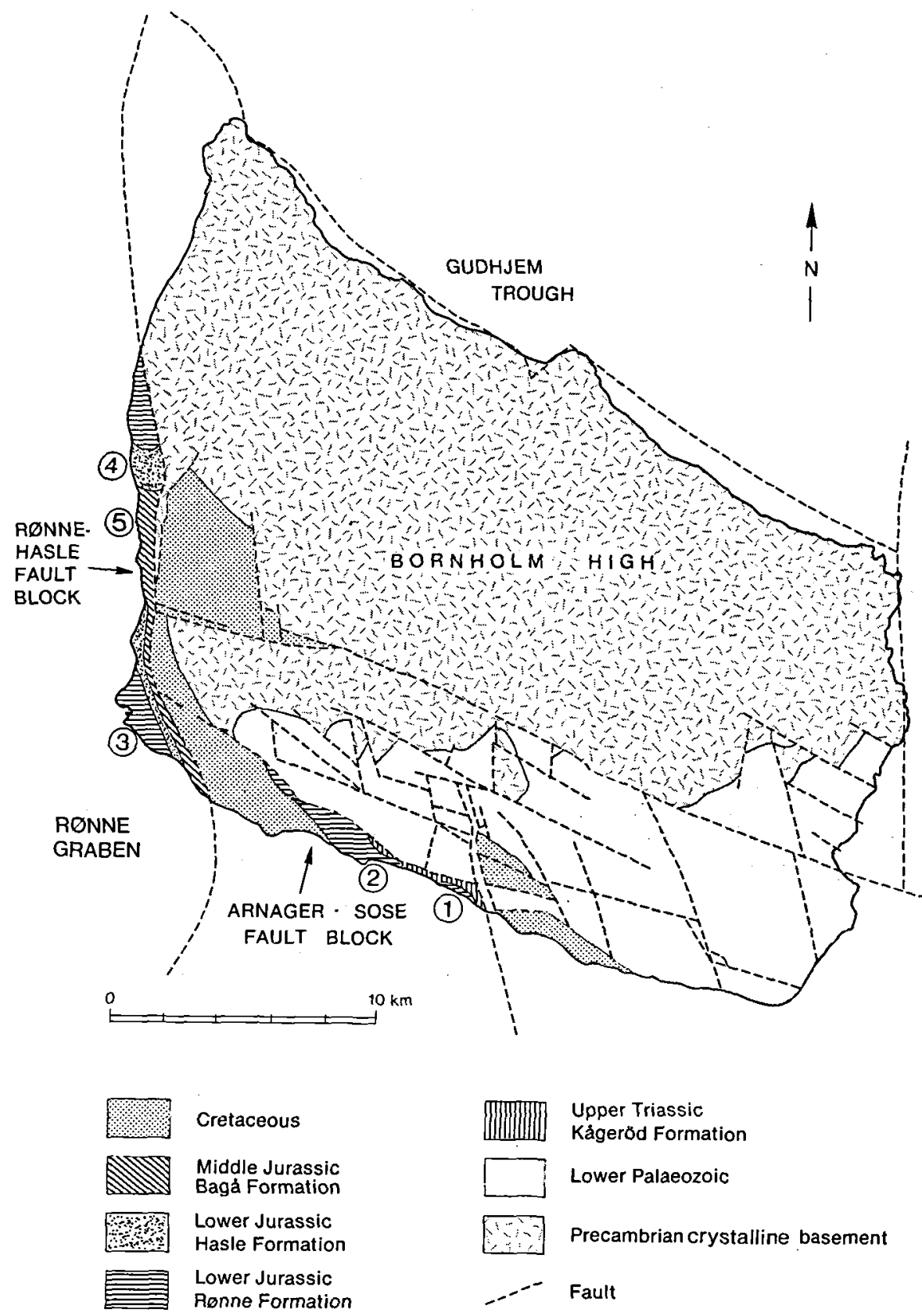

Fig. 2. Geological map and structural elements of the Bornholm area. Encircled numbers indicate type sections: Munkerup Member (1), Sose Bugt Member (2), Galgeløkke Member (3), Hasle Formation (4), Bagå Formation (5). Based on Gravesen et al. (1982).

\section{Methods}

All of the samples were palynologically prepared following the routine described by Gudmundson (1985). 10-75 grams of each were ground to a grain size of about $1 \mathrm{~mm}$. They were then packed in bags of filter cloth with a mesh size of $10 \mu \mathrm{m}$, and washed with citric acid in a standard washing machine to remove calcareous matter. Afterwards the samples were treated in a HF-maceration tank with cold commercial grade hydrofluoric acid for 8-15 days to remove mineral matter. 


\begin{tabular}{|c|c|}
\hline & Maastrichtian \\
\hline & Campanian \\
\hline $\bar{z}$ & Santonian \\
\hline 5 & Coniacian \\
\hline & Turonian \\
\hline g̈ & Cenomanian \\
\hline $\mathrm{g}$ & Albian \\
\hline & Aptian \\
\hline$\overline{\mathbf{y}}$ & Barremian \\
\hline$\stackrel{9}{9}$ & Hauterivian \\
\hline & Valanginian \\
\hline & Ryazanian \\
\hline & Volgian \\
\hline م⿳亠口冖. & Kimmeridgian \\
\hline & Oxfordian \\
\hline & Callovian \\
\hline$\stackrel{0}{2}$ & Bathonian \\
\hline 品 & Bajocian \\
\hline$气$ & Aalenian \\
\hline & Toarcian \\
\hline 5 & Pliensbachian \\
\hline 奥 & Sinemurian \\
\hline & Hettangian \\
\hline & Rhaetian \\
\hline ఏ & Norian \\
\hline & Carnian \\
\hline$\overline{\frac{2}{7}}$ & Ladinian \\
\hline$\frac{\pi}{2}$ & Anisian \\
\hline 产 & Scythian \\
\hline & Permian \\
\hline & Carboniferous \\
\hline & Devonian \\
\hline & Silurian \\
\hline & Ordovician \\
\hline & Cambrian \\
\hline & Precambrian \\
\hline
\end{tabular}

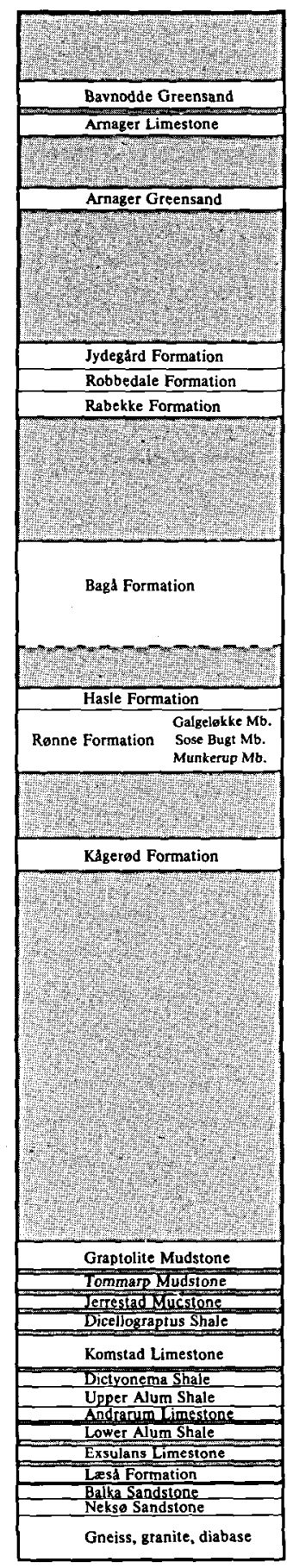

BORNHOLM

Fig. 3. Stratigraphic scheme for Bornholm, based on Michelsen (1986).

The residues of the samples were then washed with water in the tank until they were neutral (about 2 days), washed again in the washing machine with citric acid at $90^{\circ} \mathrm{C}$ and then twice with water at $50^{\circ} \mathrm{C}$. Heavy liquid separation was used if necessary. Finally, the material was swirled to separate the lighter material from the heavier. The organic residue of each sample was mounted in glycerin jelly. Several slides of each preparation were examined under a microscope, for transmitted light.

\section{Results}

The three sections of the Rønne Formation yielded rich and well preserved spores and pollen. Pinuspollenites minimus and Chasmatosporites hians are abundant in the assemblages from the Munkerup and lower part of the Sose Bugt Members. The presence of these two species and the lack of Cerebropollenites macroverrucosus indicate the presence of the Pinuspollenites - Trachysporites Zone of Lund (1977), which he dated as Hettangian.

In the assemblages from the upper part of the Sose Bugt and the Galgeløkke Members specimens of Pinuspollenites minimus continue to be common and Cerebropollenites macroverrucosus occurs sporadically. The assemblage is assigned to Lund's (op. 'cit.) unnamed zone with Cerebropollenites macroverrucosus, which he referred to the Sinemurian.

The palynomorphs in the preparations from the Hasle Formation did not yield any useful stratigraphic information.

The samples from the Bagå Formation proved to be rich in such Middle Jurassic spores and pollen grains as Ischyosporites variegatus, Manumia variverrucata, Sestrosporites pseudoalveolatus, and different species of the genera Leptolepidites and Callialasporites. The association confirms the latest late Toarcian to Bathonian age previously suggested for the formation (Hoelstad 1985).

Reworked Carboniferous spores were found in the Sose Bugt and the Galgeløkke Members. Counts of 200 palynomorphs per slide were found to include one to ten, with an average of four, of Carboniferous age. None was recovered from the Munkerup Member, Hasle Formation or Bagå Formation, although Hoelstad (1985) reported a 


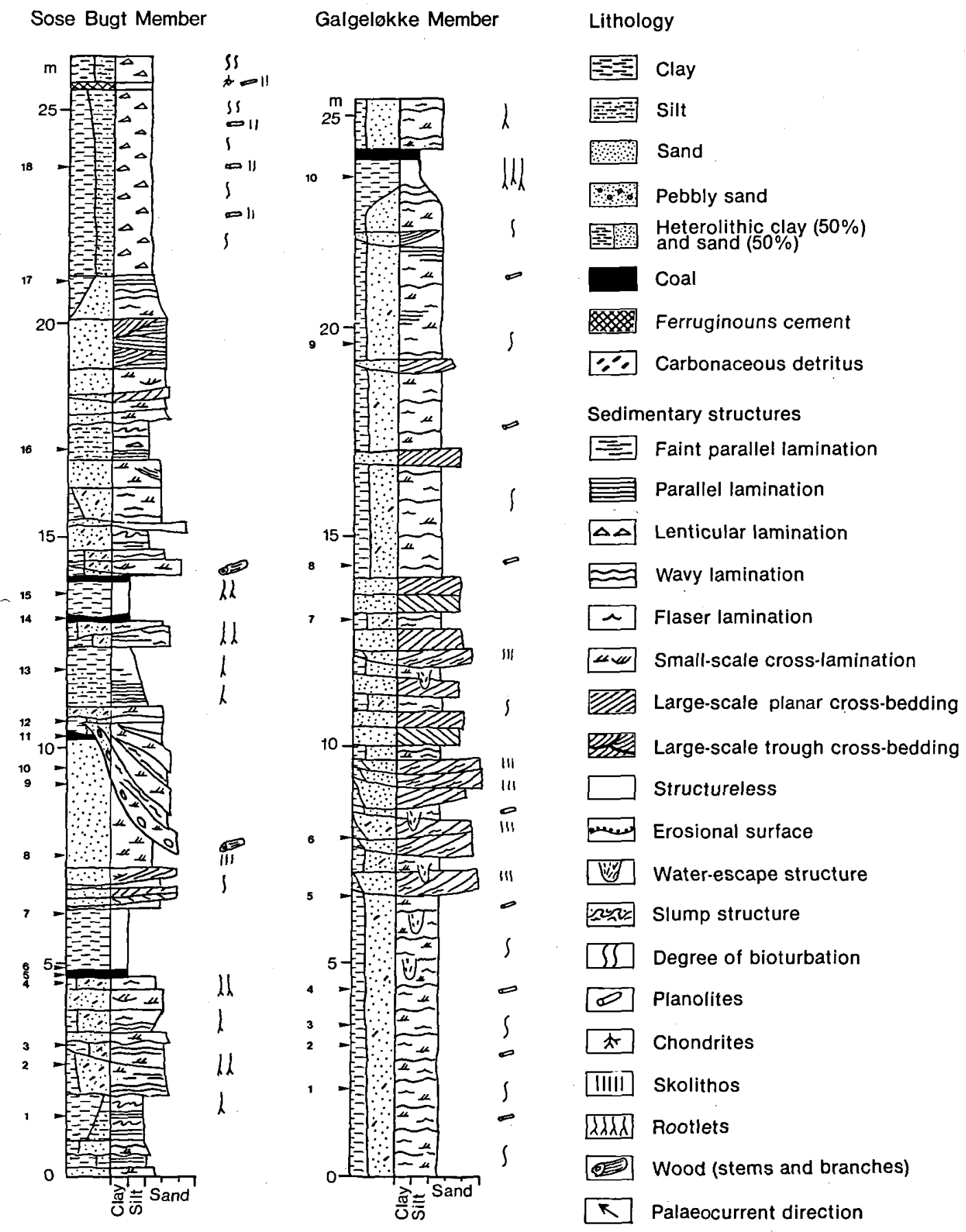

Fig. 4. Type section of the Sose Bugt Member (left) and the Galgeløkke Member (right). Position of the investigated samples is indicated by arrows (from Gravesen et al. 1982). 

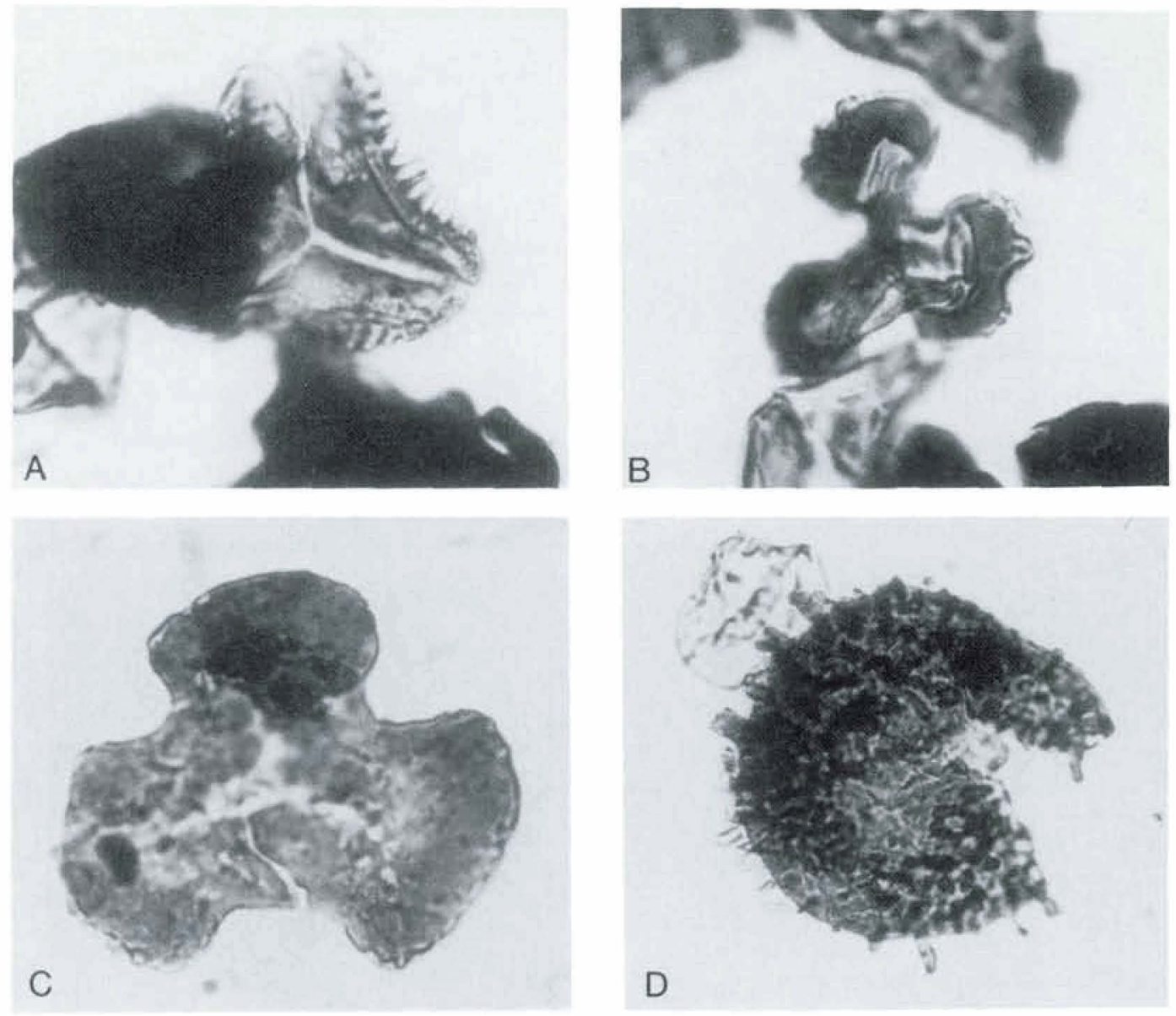

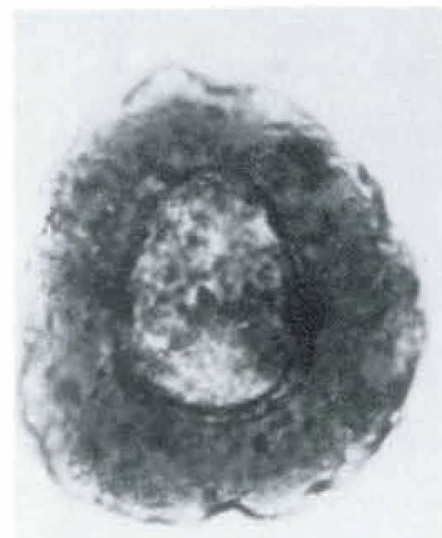

E

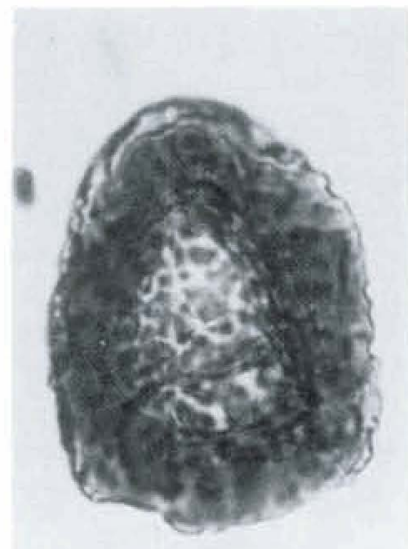

F

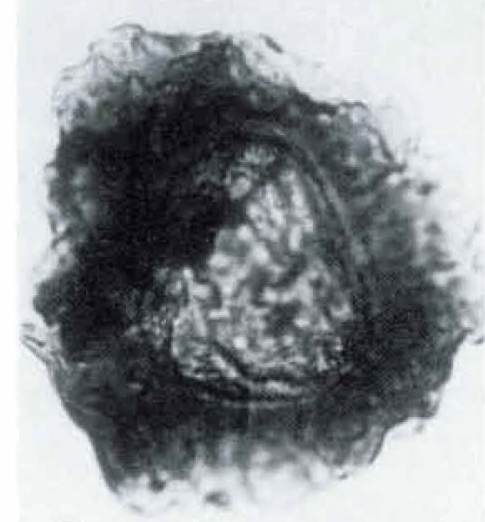

G

Fig. 5. Reworked Carboniferous spores from Lower Jurassic deposits on Bornholm. Magnification approximately x1000.

A: Diatomozonotriletes saetosus (Hacquebard \& Barss) Hughes and Playford 1961. B: Tripartites trilinguis (Horst) Smith \& Butterworth 1967. C: Tripartites vetustus Schemel 1950. D: Raistrickia nigra Love 1959. E. F \& G: Densosporites variabilis (Waltz) Potonié \& Kremp 1956 
single specimen of cf. Platyptera triloba Naumova from the latter.

The most common Carboniferous spores are Densosporites variabilis (figs $5 \mathrm{E}, 5 \mathrm{~F}$ and $5 \mathrm{G}$ ), Densosporites anulatus (fig. 6A), Lycospora pusilla (figs 6C and 6E) and Lycospora pellucida (fig. 6D) These species are geographically widespread (USSR, northwest Europe, UK and USA) and their stratigraphical range (fig. 7) is from Visean to Westphalian D, apart from that for Densosporites variabilis which is from Tournaisian to Stephanian (Luber \& Waltz 1938, Smith \& Butterworth 1967, Bertelsen 1972, Clayton et al. 1977, Ravn 1979, 1986). Other reworked species are rare but have short ranges. These include Diatomozonotriletes saetosus (fig. 5A) and Tripartites trilinguis (fig. 5B), which occur in the uppermost Visean and Namurian, and Tripartites vetustus (fig. 5C) and Raistrickia nigra (fig. 5D), which occur only in the uppermost Visean and Namurian A (fig. 7) (Luber \& Waltz 1938, Hacquebard \& Barss 1957, Dybova \& Jachowicz 1957, Hughes \& Playford 1961, Smith \& Butterworth 1967, Bertelsen 1972, 1977, Neves et al. 1972, and Clayton et al. 1977). This suggests that at least some of the source sediments must have been originally deposited during the latest Visean and Namurian A.

The reworked specimens differ significantly from the Lower Jurassic spores in size, shape, and colour. Their colour corresponds to an approximate TAI (Thermal Alteration Index) value of 5 on the scale of Batten (1980) in contrast to a value of 2 for the Jurassic assemblage. The preservation is good (see figs 5 and 6 ), which suggests a relatively short distance of transport.

The stratigraphic order of occurrence of the redeposited spores does not show any reverse appearance, i.e. the youngest Carboniferous spores are not present in the oldest Jurassic sediments. This may suggest that the source sediments represent only the interval from uppermost Visean to Namurian A.

All of the reworked species are known from Carboniferous miospore assemblages described from northwest European paralic sediments by Smith et al. (1967) and Clayton et al. (1977). Farther east, in the Moscow Basin, the contemporaneous deposits consist of marine limestones, with a different palynomorph assemblage. It is, therefore, concluded that the source sediments belonged to the northwest European paralic realm.

Species of Tripartites, Densosporites and Lycospora have previously been reported as reworked in the Rhaetian and Lower Jurassic deposits in the Rødby-1 well (Lund 1977) and in the Lower Jurassic of the Gassum-1 well (Dybkjær 1988). Furthermore, reworked Carboniferous spores are found commonly in Rhaetian and Jurassic deposits in Scania (Nilsson 1958, Guy 1971, Tralau et al. 1972, Guy-Ohlson, D., Lindquist, B. \& Norling, E. 1987). The Carboniferous spores from Scania were determined to be of Namurian age on the basis of the presence of Tripartites (Guy-Ohlson et al. 1987).

\section{Provenance area for the reworked Carboniferous palynomorphs}

\section{Present day distribution of Carboniferous} sedimentary rocks

Carboniferous deposits are well-known from a wide west-east trending belt extending from Ireland to England and Scotland, the southern North Sea, Holland, West Germany, East Germany, and Poland (e.g. Bartenstein 1979). In the Danish onshore and west Baltic areas, the northern limit of Carboniferous deposits coincides with the southern flank of the Ringk $\emptyset$ bing-Fyn High and the faults extending eastward to the Arkona Block (fig. 1). Carboniferous as well as other upper Palaeozoic deposits are unknown from Bornholm, Sweden and Finland. However, the present northern limit is mainly erosional due to later uplift, and does not preclude the occurrence of Carboniferous sedimentary rocks in the Danish Basin. Upper Carboniferous limestone has been reported from the Oslo Graben (Olaussen 1981, Bergström, Bless \& Paproth 1985) and Carboniferous deposits have been suggested to occur in the Horn Graben (Vejbæk 1990).

In the Danish area, south of the RingkøbingFyn High, Carboniferous rocks have been demonstrated in the $\emptyset$ rslev- 1 well located south of the Møn Block (fig. 1). More than $500 \mathrm{~m}$ of Lower-Middle Visean beds of alternating claystones, marls, and limestones were encountered. These are separated from overlying Permian (or Upper Carboniferous ?) red beds by an angular 
unconformity (Michelsen 1971, 1972, Bertelsen 1972). In the Hønning-1 well (fig. 1), a pre-Permian, steeply dipping shale of possible Carboniferous age is present below an angular unconformity (Sorgenfrei \& Buch 1964), and in the recently drilled Borg-1 well located in the same area, shales of Carboniferous age were encountered (Underwood 1988).

On the island of Rügen, offshore East Germany, and offshore Poland south of Bornholm, Lower and Upper Carboniferous rocks rapidly wedge out towards the north because of faulting and truncation before the Permian sediments were deposited (Dadlez 1974, 1987). In the southeastern Baltic area, Devonian and Lower Carboniferous rocks are truncated by erosion (Flodén 1980), and the western margin of the Carboniferous in northwest Russia is also a result of erosion (Bergström et al. 1985). A reconstruction of the Carboniferous palaeogeography is hampered by the extensive later erosion, and palaeogeographical maps prepared by various authors differ considerably (e.g. Bertelsen 1972, Michelsen 1972, Ziegler 1982, 1988, Glennie 1984, Bergström et al. 1985, Dadlez 1987).

During the Visean, deposition of marine carbonates dominated in northwest Europe, northern East Germany, and Poland. A gradual change to deposition of continental and marginal marine clastics in the Variscan foredeep occurred during the Namurian and Westphalian, with input from the Variscan Foldbelt to the south, and the Scottish Highlands and the Fennoscandian area in the north (Ziegler 1982, 1988, Glennie 1984, Bergström et al. 1985, Dadlez 1987). In the northern part of East Germany and Poland, clastic paralic and limnic sedimentation occurred in increasingly isolated basins because of decreasing rates of subsidence. At the end of the period the area became emergent. This resulted in an incomplete Upper Carboniferous sequence in northwest Poland and the northern part of East Germany, with a Namurian hiatus presumably of non-depositional origin and a restricted areal extent of Westphalian owing to both non-deposition and erosion (Pozaryski \& Dembowski 1984, Dadlez 1987, Ziegler 1988).
Early Jurassic palaeogeography and depositional environment

The Rønne Formation constitutes a heterogeneous sequence of interbedded sand, silt, and clay, approximately $500 \mathrm{~m}$-thick in the Rønne-Hasle Fault Block and approximately $200 \mathrm{~m}$-thick in the Arnager-Sose Fault Block (fig. 2). Thin autochtonous coal beds and dark clays with rootlets are fairly common, and dispersed organic matter and fragments of leaves and woody material occur throughout. The trace fossils Skolithos and Planolites are abundant locally. Except for rare occurrences of the brackish bivalves Cardinia follini and Cyrena menki, macrofossils are absent and only a few agglutinating foraminifera have been found.

The formation is interpreted as fluvio-deltaic and tidal marine (Gry 1969, Sellwood 1972, Rolle, Koch, Frandsen \& Surlyk 1979, Gravesen et al. 1982). The depositional environment is similar to that for the relatively coarse-grained deltaic and marginal marine deposits occurring at the basin margin along the Fennoscandian Border Zone, as represented by the Gassum Formation in North Jylland and North Sjælland, the Helsingborg Member of the Höganäs Formation in Scania, and the Mechowo and Radowo Beds in NW Poland. Marine shelf claystones occur more centrally in the Danish Basin (Dadlez \& Kopik 1972, Michelsen 1975, 1978, Bertelsen 1978, Sivhed 1984, Pedersen 1985, Dadlez 1987, Nielsen, Larsen \& Frandsen 1989).

Clastic material shed into the Danish Basin was mainly derived from the Fennoscandian Shield northeast of the Border Zone (Larsen 1966). Areas south of the Ringkøbing-Fyn High and south and east of Bornholm are precluded as provenance areas for the Rønne Formation because contemporaneous sediments accumulated on top of the Triassic in these areas (Bertelsen \& Michelsen 1970, Michelsen 1973, Dadlez 1974, 1987, Lund 1977, Norling \& Skoglund 1977, Kumpas 1978, 1979). Besides the Fennoscandian Shield, it is also possible that local highs contributed to the formation of the Rønne Formation, e.g. the Skurup High, where Upper Cretaceous sediments locally rest on basement (Vejbæk 1985, figs 6 and 7), and the Bornholm High where lower Palaeozoic sediments and Precambrian crystalline basement are exposed today. 


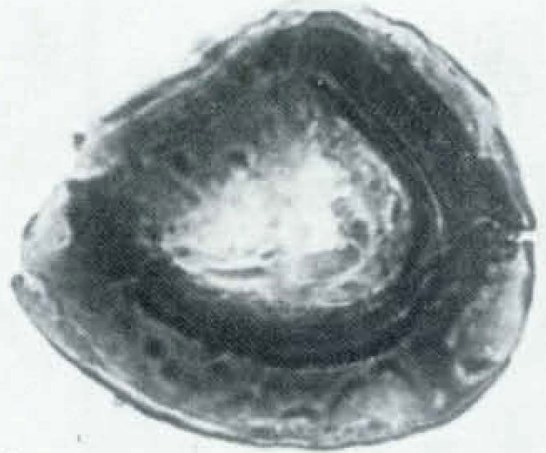

A

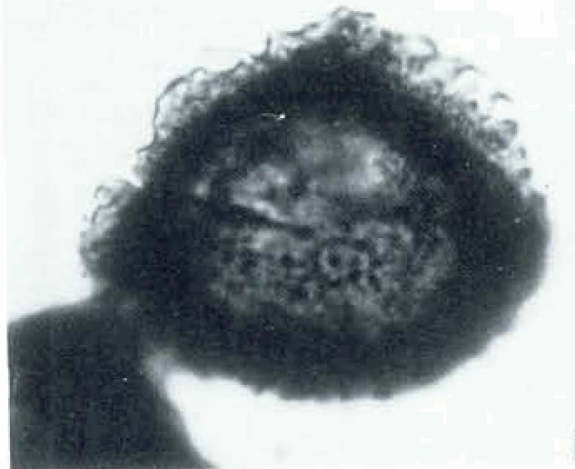

B
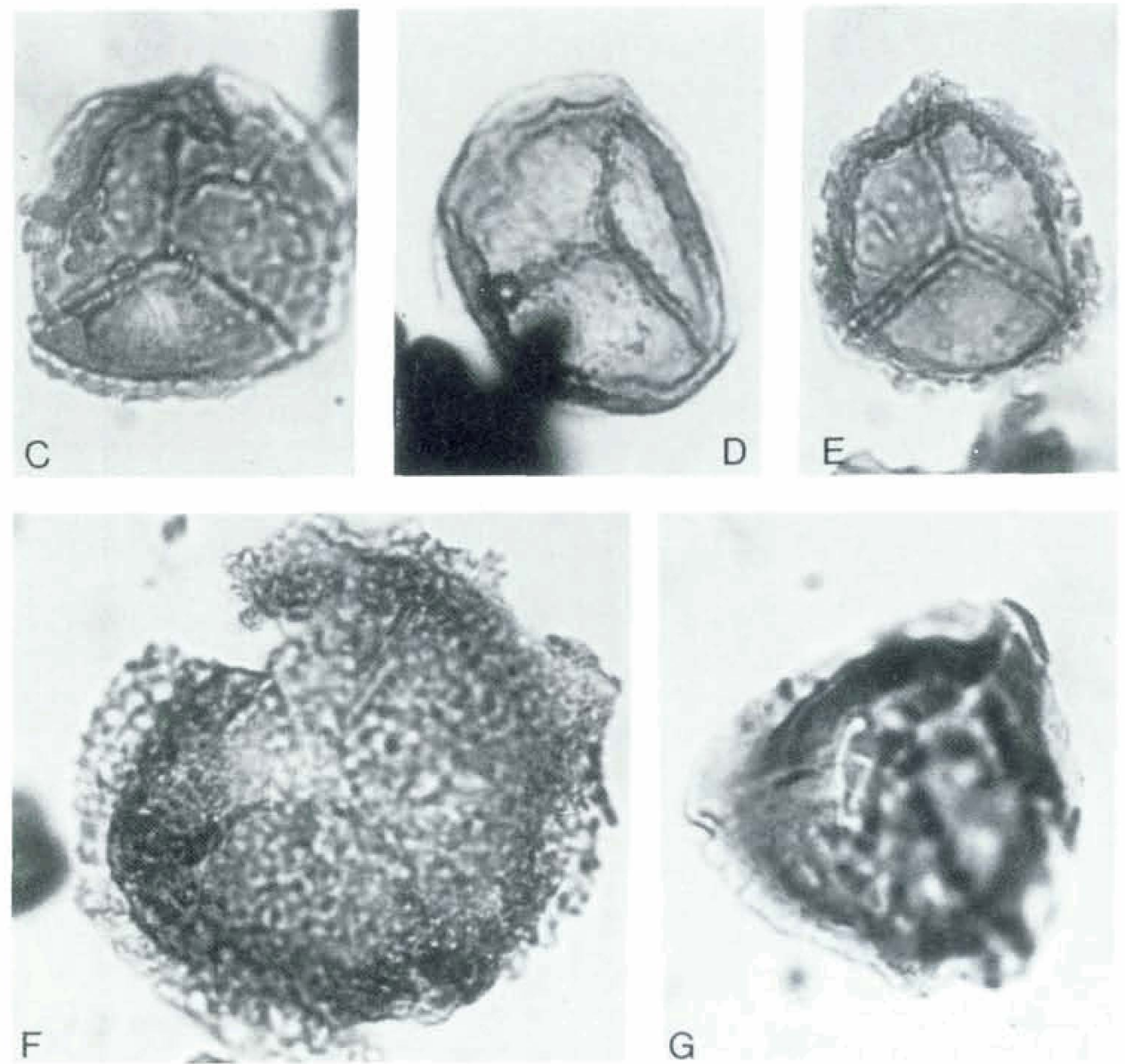

Fig. 6. Reworked Carboniferous spores from Lower Jurassic deposits on Bornholm. Magnification approximately x1000.

A: Densosporites anulatus (Loose) Smith \& Butterworth 1967. B: Densosporites sp. C \& E: Lycospora pusilla (Ibrahim) Schopf. Wilson et Bentall 1944. D: Lycospora pellucida (Wicher) Schopf. Wilson et Bentall 1944. F \& G: Lvcospora sp. 
Colonus Trough and found high values corresponding to a post-mature stage. He interpreted this to be related to the presence of intrusives because he believed that the degree of heating associated with the depth of burial would have been insufficient to cause such a change in maturation level. However, the Palaeozoic burial history of Scania is difficult to assess (e.g. Bergström 1984). Cambrian-Silurian sediments with thicknesses of up to $4 \mathrm{~km}$ occur in areas structurally linked to the Colonus Trough, such as the Fjerritslev Trough, and locally in the Kattegat area and south and east of Bornholm (Vejbæk 1985, Liboriussen et al. 1987, Ro et al. 1990). This is suggestive of a regional subsidence during early Palaeozoic times. Isotope data from Ordovician limestones on Bornholm (Buchardt \& Nielsen 1984) and fission track analyses from southern Sweden (Zeck et al. 1988) support this.

Guy-Ohlson et al. (1987) measured TAI values in Scania of 6 and 3 for the Carboniferous and Jurassic spores respectively. In the material from Bornholm, the analogous values are 5 and 2, corresponding to approximate vitrinite reflectance of 0.9 and 0.3 (Batten 1980). The latter value was confirmed by direct measurement, giving a range from $0.3-0.4$. The TAI values clearly indicate a pronounced thermal alteration of the Carboniferous spores to a mature stage. It is thus possible that major subsidence of the Colonus Trough continued during the Permo-Carboniferous tectonic phase, which would explain the high CAI values and allow maturation of the Carboniferous sediments and their preservation until Late Triassic - Early Jurassic time. A thorough evaluation of the maturation profile is prevented because relationships between CAI, TAI and vitrinite reflectance measurements are somewhat ambiguous, and insufficient data are available on the thicknesses of the Silurian, the upper Palaeozoic, and the Triassic. However, the general trend of post-mature Ordovician, mature Carboniferous, and pre-mature Jurassic is significant.

The localities in Scania with reworked Carboniferous spores are situated in the northwestern part of the Colonus Trough, and the Bornholm area is at the southeastern end (fig. 1). Jurassic deposits are absent in the central part mainly because of erosion caused by post-Jurassic inversion movements. However, initial upheaval of the Colonus Trough and the central part of the Scania fault zone by inversion tectonics may have already occurred during the Late Triassic and Early Jurassic (Kumpas 1984, Norling 1984, Norling \& Bergström 1987). Such movements could have provided uplifted blocks with Carboniferous sediments which became source areas during the Jurassic. Based on the proportional frequency and degree of preservation of reworked Carboniferous spores in different well sections in Scania, Guy-Ohlson \& Norling (1988) suggested that the "Söderåsen« block (fig. 1) was such a source area, indicating a very local origin.

Reworked Carboniferous spores are present in the major part of the Jurassic of Scania (GuyOhlson et al. 1987), but have only been found in the Lower Jurassic of Bornholm, except for a single specimen in the Middle Jurassic (Hoelstad 1985). This may suggest that erosion of the Bornholm High during the Early to Middle Jurassic progressed downwards through a Carboniferous and lower Palaeozoic sedimentary cover down to the crystalline basement. Alternatively, it may indicate that the dominating source area of the Bagå Formation at the type locality was the immediately adjacent basement horst, also as indicated by the large boulders of kaolinized basement embedded in the formation.

\section{Conclusion}

Reworked Carboniferous spores occur commonly in Jurassic deposits of Europe (Windle 1979) and is in most cases related to local reworking of Carboniferous rocks. The common presence of Carboniferous spores in the Lower Jurassic on Bornholm, and in the Lower, Middle, and Upper Jurassic of Scania, suggests that sediments of late Visean to Namurian age were originally present in Scania and possibly also on Bornholm. It is proposed that the Carboniferous deposits were preserved in the down-faulted Colonus Trough until the Jurassic as a result of PermoCarboniferous transtensional fault movements. During the initial uplift of the area in Late Triassic to Early Jurassic time with associated local block faulting, the Carboniferous deposits were exposed and eroded. Owing to further inversion during the Kimmerian tectonic phases, source areas with Carboniferous deposits were contin- 
ually renewed during the Jurassic as indicated by the occurrence of Carboniferous spores in the major part of the Swedish Jurassic.

The former presence of Carboniferous deposits in the Scania-Bornholm area makes it possible that equivalent deposits are preserved in downfaulted areas around Bornholm such as the Rønne Graben, where subsidence occurred during most of the Mesozoic Era. If present, such rocks may possess an exploration potential, as Carboniferous strata are important sources of hydrocarbons in many fields in northwest Europe (e.g. Bartenstein 1979).

\section{Acknowledgments}

The paper was written while L.H. Nielsen was in receipt of a postgraduate grant from the Danish Research Academy and the Geological Survey of Denmark and supervised by $\mathrm{O}$. Michelsen (Århus) and F. Surlyk (Copenhagen). E.B. Koppelhus was supported by a grant from the Carlsberg Foundation and supervised by $O$. Michelsen and S. Piasecki (Geological Survey of Greenland). The supervisors and our colleagues $O$. Vejbak, N. E. Hamann, and E. Thomsen are acknowledged for valuable discussions. H. Andersen typed the paper; G. Nicolajsen, H. Klinge Petersen and B. Scharck made the figures. David J. Batten is thanked for critical reading the manuscript and making many suggestions for its improvement.

\section{Dansk sammendrag}

Palynologisk analyse af aflejringer fra nedre jura på Bornholm har vist, at karbone sporer forekommer sporadisk i en palynomorf flora af hettangien til sinemurien alder. Tilsvarende omlejrede karbone sporer er også fundet i øvre trias og jura aflejringer $\mathrm{i}$ Skåne. Deres hyppighed og forholdsvis velbevarede form udelukker lang og gentagen transport. Tilstedevarelsen af de karbone sporer er interessant, fordi karbone aflejringer ikke findes i dag i det jurassiske kildeområde, som hovedsagelig var det Fennoskandiske Skjold. Karbone aflejringer findes i dag i området syd for Ringkøbing-Fyn Højderyggen og Arkona blokken, men det kan udelukkes, at sporerne stammer fra dette område. Det foreslås derfor, at karbone sedimenter af sen viséen til namurien $A$ alder blev aflejret i Skåne- og Bornholmsområdet og hovedsageligt blev bevaret $i$ områder som Colonus Truget og Rønne Graven, der var præget af extension tektonik i sen karbon - tidlig perm. På grund af hævning i sen trias og jura blev de karbone aflejringer eroderet og palynomorferne indlejret $i$ yngre sedimenter. Hvis karbone aflejringer endnu er tilstede i Rønne Graven, kan de фge prospektiviteten af området, idet karbone aflejringer er vigtige moderbjergarter for hydrokarboner i mange felter i nordvest Europa.

\section{References}

Bartenstein, H., 1979: Essay on the coalification and hydrocarbon potential of the Northwest European Palaeozoic. Geol. Mijnbouw. 58 (1), 57-64.
Batten, D. J., 1980: Use of transmitted light microscopy of sedimentary organic matter for evaluation of hydrocarbon source potential. Proceedings IV. Int. Paly. Conf. Lucknow (1976-77), 2, 589-594.

Bergström, J., 1984: Summary of scientific presentations. Geol. Fören. Stock. Förh., 106 (4), 379-380.

Bergström, J., Bless, J.M. \& Paproth, E., 1985: The marine Knabberud Limestone in the Oslo Graben: possible implications for the model of Silesian paleogeography. $Z$. Dtsch. Geol. Ges., 136, 181-194.

Bergström, S. M., 1980: Conodonts as paleotemperature tools in Ordovician rocks of the Caledonides and adjacent areas in Scandinavia and the British Isles. Geol. Fören. Stock. Förh., 102 (4), 377-392.

Bertelsen, F, 1972: A lower Carboniferous microflora from the

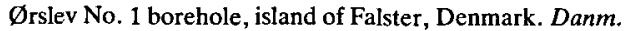
geol. Unders.II Rakke 99, 78 pp.

Bertelsen, F., 1977: Carboniferous miospores from the Nords $\varnothing$ P-1 borehole, Danish North Sea offshore area. Danm. geol. Unders., Årbog 1977, 101-111.

Bertelsen, F., 1978: The Upper Triassic - Lower Jurassic Vinding and Gassum Formations of the Norwegian-Danish Basin. Danm. geol. Unders. Ser. B 3, 26 pp.

Bertelsen, F. \& Michelsen, 0., 1970: Megaspores and Ostracods from the Rhaeto-Liassic Section in the Boring Rødby No. 1 Southern Denmark. Danm. geol. Unders. II Rakke 94, 60 pp., 16 pls.

Buchardt, B. \& Nielsen, A.T., 1984: Carbon and oxygen isotope composition of Lower Paleozoic carbonate rocks from Bornholm. Evidence of deep burial diagenesis. Geol. Fören. Stock. Förh., 106 (4), 383-384.

Clayton, G., Coquel, R., Doubinger, J., Gueinn, K.J., Loboziak, S., Owens, B. \& Streel, M., 1977: Carboniferous Miospores of Western Europe: illustration and zonation. Meded. Rijks geol. Dienst, 29, 1-71.

Dadlez, R., 1974: Some geological problems of the Southern Baltic Basin. Acta Geologica Polonica, 24, (1), 261-275.

Dadlez, R., 1987: Evolution of the Phanerozoic basins along the Teisseyre-Tornquist zone. Z. angew. Geol., 33, 9, 229233.

Dadlez, R. \& Kopik, G., 1972: Selected problems of Liassic stratigraphy and sedimentation in the area between Swinenjecie and Gryfice (north-west Poland). Kwart. Geol., 16, 620-636. (In Polish with English summary).

Dybkjær, K., 1988: Palynological zonation and stratigraphy of the Jurassic section in the Gassum No. 1-borehole, Denmark. Danm. geol. Unders. Ser. A Nr. 21. 72 pp.

Dybova, S. \& Jachowicz, A., 1957: Microspores of the Upper Silesian coal measures. Prace Inst. geol., 23, 1-328.

Flodén, T., 1980: Seismic stratigraphy and bedrock geology of the central Baltic. Acta Univers. Stockholmiensis, Stockholm Contrib. Geol., 35, 240 pp., Stockholm.

Glennie, K. W., 1984: The Structural Framework and the PrePermian History of the North Sea Area. In: Glennie, K.W. (ed.): Introduction to the Petroleum Geology of the North Sea. Blackwell Scientific Publications, 236 pp.

Gravesen, P., Rolle, F., and Surlyk, F., 1982: Lithostratigraphy and sedimentary evolution of the Triassic, Jurassic and Lower Cretaceous of Bornholm, Denmark. Danm. geol. Unders. Ser. B No.7. 51 pp.

Gry, H., 1960: Geology on Bornholm. - Guide to Excursions Nos. A 45 and C 40. Int. Geol. Congr. 21 Sess. Copenhagen, $16 \mathrm{pp}$.

Gry, H., 1969: Megaspores from the Jurassic of the island of Bornholm. Medd. Dansk Geol. Foren. 19, 69-87.

Gudmundson, L., 1985: Nedsyring af uorganiske materialer ved hjxlp af massenedsyringsmetoden (Macerationstankmetoden). Palyno-Nytt 2, 3-6. (In Danish).

Guy, D., 1971: Palynological investigations in the Middle Ju- 
rassic of the Vilhelmsfält Boring, Southern Sweden. Inst. Min. Palae. Quat. Geology. Univ. Lund, No. 168, 109 pp.

Guy-Ohlson, D., Lindquist, B. \& Norling, E., 1987: Reworked Carboniferous spores in Swedish Mesozoic sediments. $\mathrm{Ge}$ ol.Fören. Stock., Förh., 109 (4), 295-306.

Guy-Ohlson, D. \& Norling, E., 1988: Upper Jurassic Lithoand Biostratigraphy of NW Scania, Sweden. Sver. Geol. Unders. Ser. Ca 72, $37 \mathrm{pp}$.

Hacquebard, P. A. \& Barss, M. S., 1957: A Carboniferous spore assemblage in coal from the South Nahanni River area, Northwest Territories. Bull. geol. Surv. Can., 40, $1-63$.

Hoelstad, T., 1985: Palynology of the uppermost Lower to Middle Jurassic strata on Bornholm, Denmark. Bull. geol. Soc. Denmark, 34, 111-132.

Hughes, N. F. \& Playford, G., 1961: Palynological reconnaissance of the Lower Carboniferous of Spitsbergen. Micropaleontology, 7, 1, 27-44.

Jensen, J. B. \& Hamann, N. E., 1989: Geological mapping of Mesozoic deposits along the eastern margin of the Ronne Graben, offshore Bornholm, Denmark. Bull. geol. Soc. Denmark, 37, 237-260.

Klingspor, J., 1976: Radiometric age-determination of basalts, dolorites and related syenite in Skåne, southern Sweden. Geol. Fören. Stockholm Förh., 98, 195-216.

Koppelhus, E. B., 1988: Omlejrede karbone sporer i mesozoiske sedimenter fra Bornholm. Palyno-Nytt, 7, 8-9. (In Danish).

Kumpas, M. G., 1978: Distribution of sedimentary rocks in the Hanö bay and south of land. Stockholm Contributions in Geology, 31, 3, 95-103.

Kumpas, M. G., 1979: Seismic Stratigraphy and Tectonics in the Hanö bay. Stockholm Contributions in Geology, 34, 4, 35-168.

Kumpas, M. G., 1984: Seismic interpretation of the Tornquist Zone in Denmark and Sweden. Geol. Fören. Stock. Förh. $106,4,388-389$.

Larsen, G., 1966: Rhaetic-Jurassic-Lower Cretaceous Sediments in the Danish Embayment (A Heavy-Mineral Study). Danm. geol. Unders. II Rakke 91. $127 \mathrm{pp.}$

Liboriussen, J., Ashton, P. \& Tygesen, T., 1987: The tectonic evolution of the Fennoscandian Border Zone in Denmark. Tectonophysics, 137, 21-29.

Love, L. G., 1959: Assemblages of Small Spores from the Lower Oil-shale Group of Scotland. Proc. Roy. Soc. Edinb. LXVII B 1958-59, part II, 99-126.

Luber, A. A. \& Waltz, I. E., 1938: Classification and stratigraphical value of spores of some Carboniferous coal deposition in the U.S.S.R., Trans. Inst. Geol. U.S.S.R., $105,1-45$.

Lund, J. J., 1977: Rhaetic to Lower Liassic palynology of the onshore south-eastern North Sea Basin. Danm. geol. Unders. II Række. 109, 1-129.

Michelsen, O., 1971: Lower Carboniferous Foraminiferal Faunas of the Boring Ørslev No. 1, Island of Falster, Denmark. Danm. geol. Unders. II Rakke 98, 86 pp.

Michelsen, O., 1972: Den nedre karbone lagserie i boringen Ørslev nr. 1 og dens foraminiferfauna. Dansk geol. Foren., Arsskrift for 1971, 95-100. (In Danish).

Michelsen, O., 1973: On Liassic holothurian and ostracod assemblage from the Danish Embayment. Danm. geol. Unders., Ärbog 1972, 49-68.

Michelsen, O., 1975: Lower Jurassic biostratigraphy and ostracods of the Danish Embayment. Danm. geol. Unders. II Række 104, 287 pp.

Michelsen, O., 1978: Stratigraphy and distribution of Jurassic deposits of the Norwegian-Danish Basin. Danm. geol. Unders. Ser. B 2.28 pp.

Michelsen, O., 1986: The Danish pre-Tertiary lithostratigraphy. - Status of the lithostratigraphic nomenclature, onshore and offshore Denmark. Danm. geol. Unders., Internal report, 12, 9 pp.

Neves, R., Gueinn, K. F., Clayton, G., Ioannides, N. S. \& Neville, R. S. A., 1972: A scheme of miospore zones for the British Dinantian. C.R. 7th Congr. Int. Carb. Strat. Geol. Krefeld I, 347-353.

Nielsen, L. H., Larsen F, Frandsen N., 1989: Upper Triassic Lower Jurassic deposits of the Gassum Formation on Sjælland, Denmark. Danm. geol. Unders., Ser. A $23.30 \mathrm{pp}$.

Nilsson, T., 1958: Uber das Vorkommen eines Mesozoischen Sapropelgesteins in Schonen. Lunds Universitets Årsskrift N.F. Avd. 2, Bd. 54, Nr. 10, 127 pp.

Norling, E., 1984: Kimmerian tectonics, stratigraphy and paleogeography of Scania. Geol. Fören. Stockh. Förh., 106, 4, 392-394.

Norling, E. \& Bergström, J.; 1987: Mesozoic and Cenozoic tectonic evolution of Scania, southern Sweden. In: P.A. Ziegler (ed.): Compressional Intra-Plate Deformations in the Alpine Foreland. Tectonophysics, 137, 7-19.

Norling, E. \& Skoglund, R., 1977: Der Südwestrand der Osteuropäischen Tafel im Bereich Schwedens. Z. angew. Geol., $23,9,449-458$.

Olaussen, S., 1981: Marine incursion in Upper Palaeozoic sedimentary rocks of the Oslo Region, Southern Norway. Geol. Mag., 118, 3, 281-288.

Pedersen, G. K., 1985: Thin, fine-grained storm layers in a muddy shelf sequence: an example from the Lower Jurassic in the Stenlille-1 well. J. geol. Soc. London, 142, 357374.

Potonié, R. \& Kremp, G., 1956: Die Sporae dispersae des Ruhrkarbons, ihre Morphographie und Stratigraphie mit Ausblicken auf Arten anderer Gebiete und Zeitabschnitte. Teil II. Palaeontographia Abt. B 99, 4-6, 85-191, pls. 17-22.

Pozaryski, W. \& Dembovski, Z. (eds), 1984: Geological map of Poland and adjoining countries, without Cenozoic, Mesozoic and Permian formations. Scale 1:1 000 000. Contribution to IGCP Projects 166 and 86. Wydawnictwa Geologiczne Warszawa 1984.

Ravn, R. L., 1979: An introduction to the stratigraphic Palynology of the Cherokee Group (Pennsylvanian) coals of Iowa. Iowa Geological Survey Technical Paper No. 6, 1117.

Ravn, R. L., 1986: Palynostratigraphy of the Lower and Middle Pennsylvanian Coals of Iowa. Iowa Geological Survey Technical Paper No. 7, 1-245.

Ro, H. E., Stenvold, L., Fabride, J. I. \& Myhre, A. M., 1990: The Skagerak Graben - the offshore continuation of the Oslo Graben. Tectonophysics, 178, 1-10.

Rolle, F., Koch, J. O., Frandsen, N. \& Surlyk, F., 1979: Jurassic Environments in the Fennoscandian Border Zone. Symposium »Sédimentologistes Francais Publication spéciale, I, 15-31.

Schemel, M. P., 1950: Carboniferous plant spores from Daggett County, Utah. Journal of Paleontology, 24, 2, 232-244, pl. 39-40.

Schopf, J., Wilson, L. \& Bentall, R., 1944: An Annotated Synopsis of Paleozoic Spores and the Definition of Generic: Groups. Catalog of fossil Spores and Pollen, 5 (1959).

Schulz, E., 1967: Sporenpaläontologische Untersuchungen Rhätoliassischer Schichten im Zentralteil des Germanischen Beckens. Paläontol. Abt. B. 2 (3), 541-633.

Sellwood, B. W., 1972: Tidal-flat sedimentation in the Lower Jurassic of Bornholm, Denmark. Paleogeogr., Paleoclimatol., Paleoecol., 11, 99-106.

Sivhed, U., 1984: Litho- and Biostratigraphy of the Upper Triassic - Middle Jurassic in Scania, Southern Sweden. Sver. Geol. Unders., Ser. C, 806, 31 pp.

Smith, A. H. V. \& Butterworth, M. A., 1967: Miospores in the coal seams of the Carboniferous of Great Britain. Special 
Papers in Palaeontology, 1, 1-324. The Palaeontological Association, London.

Sorgenfrei, T. \& Buch, A., 1964: Deep Tests in Denmark 1935-1959. Danm. geol. Unders., III Rakke, 36, 146 pp.

Surlyk, F. \& Noe-Nygaard, N., 1986: Hummocky cross-stratification from the Lower Jurassic Hasle Formation of Bornholm, Denmark. Sedimentary. Geology 46, 259-273.

Tralau, H. \& Artursson, K., 1972: New Middle Jurassic Pollen and Spore Floras from Southern Sweden and the Öresund. Grana, 12, 57-63.

Underwood, J., 1988: 5508/32-2 (Borg-1) Danish onshore well. Biostratigraphy of the interval $10 \mathrm{~m}-3080.2 \mathrm{~m}$ TD. Robertson Group plc, Report No. 3862/Ia.

Vejbæk, O. V., 1985: Seismic stratigraphy and tectonics of sedimentary basins around Bornholm, southern Baltic. Danm. geol. Unders., A 8. 30 pp.
Vejbæk, O. V., 1990: The Horn Graben, and its relationship to the Oslo Graben and the Danish Basin. Tectonophysics, $178,29-49$.

Windle, T. M. F., 1979: Reworked Carboniferous spores: An example from the Lower Jurassic of Northeast Scotland. Rev. of Palaeo. and Paly. 27, 173-184.

Zeck, H. P., Andriessen, P. A. M., Hansen, K., Jensen, P. K. \& Rasmussen, B. L., 1988: Paleozoic paleo-cover of the southern part of the Fennoscandian Shield-fission track constraints. Tectonophysics, 149, 61-66.

Ziegler, P. A., 1982: Geological Atlas of Western and Central Europe. Elsevier, Amsterdam, $130 \mathrm{pp}$.

Ziegler, P. A., 1988: Evolution of the Arctic-North Atlantic and the Western Tethys. AAPG Memoir 43, 197 pp. \& $30 \mathrm{pl}$. 